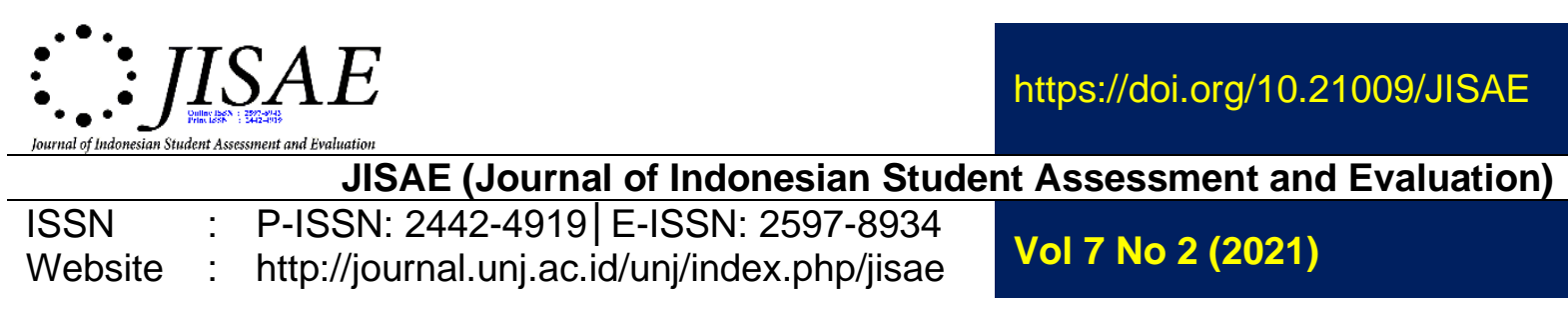

\title{
The use of the Rasch model in analysing the validity and reliability of students' coping strategy scale
}

\author{
Maya Oktaviani ${ }^{1}$ \\ Universitas Negeri Jakarta \\ Uswatun Hasanah \\ Universitas Negeri Jakarta \\ Muhammad Faesal \\ Universitas Negeri Jakarta \\ Elmanora \\ Universitas Negeri Jakarta \\ Vania Zulfa \\ Universitas Negeri Jakarta
}

\begin{abstract}
This research is part of the standardization of the Students' Coping Strategy Scale (SCSS). This study aims to reveal the content validity, empirical validity, and reliability of the SCSS. The non-test instrument consisting of 42 statements from three dimensions: problem-focused coping, emotion-focused coping, and seeking social support. Content validity analysis was carried out by experts to obtain Gregory's content validity coefficient, while the empirical validity and reliability analysis by empirically testing the instrument on 211 respondents and analysed using the Rasch model approach. The results show that Gregory's content validity coefficient is 0.714 , so it needs improvement on some items that are considered unsuitable. Empirical validity analysis using WINSTEPS software shows that three items do not fit the model. The reliability coefficient of the SCSS is 0.99 . Thus, the remaining 39 items are appropriate to be used to measure students' coping strategies.
\end{abstract}

\section{Keywords:}

Coping Strategies; Gregory Content Validity; Rasch Model
Address for Correspondence:

${ }^{1}$ maya.oktaviani@unj.ac.id

\section{INTRODUCTION}

Indonesia has become one of the countries that have implemented distance learning since the Covid-19 outbreak. The sudden change from face-to-face learning to face-to-face learning makes lecturers must innovate in providing learning. Lecturers also must adapt and learn to use these applications. Thus, some lecturers only use one type of learning application in teaching several courses. The use of only one application is an alternative solution for lecturers. Unfortunately, on the other hand, students are the ones who must learn more. In addition to understanding the material, students must adapt to their lecturers' many learning applications.

The use of various applications, of course, requires an adequate internet quota and internet network stability. The Ministry of Education and Culture provides quota subsidies for active students registered in the Higher Education database (Kemendikbud, 2020). As for internet network problems, the government cannot 
resolve them quickly. That is because not all regions in Indonesia have a good internet network. The development of internet and cellular infrastructure for underdeveloped, leading, and outermost regions is still lacking (Evandio, 2020). The United Nations (2021) data shows that distance learning is out of reach for most learners in developing countries. Lack of access to computers and the internet at home and low levels of skills in using computers make many students unable to access learning. This lack is an obstacle for some students. Such constraints can cause stress for students.

Stress is a stressful event so that a person is in a state of helplessness and has a negative impact (Lubis et al., 2015). According to Rustiana \& Cahyati (2012), stress is a condition caused by transactions between individuals and the environment that creates a perception of distance between the demands of the situation and the resources in a person's biological, psychological, and social systems. Stress can burden students. The pressure experienced by students can harm them. However, students also will not let these adverse effects last long. Therefore, students should take action to overcome this. These actions are called coping strategies (Maryam, 2017). In line with the research results of Oktaviani et al. (2020), students need coping strategies to create fun learning.

Coping is a process used by a person in dealing with stressful demands (Rustiana \& Cahyati, 2012). Coping strategies are a person's ability to overcome various problems surrounding their life (Utami \& Pratitis, 2013). Coping strategies are considered self-regulation abilities (Sullivan, 2010). On the other hand, self-regulation is an attempt by persons to control their behaviour. Students have done many things during distance learning activities. Oktaviani et al. (2020) summarize some activities that students do to keep learning fun: daily writing journals, positive thinking, interacting with friends and family, and creating a learning atmosphere at home like studying in class, delaying doing assignments.

As the next generation of the nation, students must face the problems that exist today. Thus, it is necessary to have appropriate coping strategies to survive and continue to follow learning well. In achieving these goals, it is necessary to have an instrument that can measure students' coping strategies.

Based on some of these opinions, coping is an individual's response to stress caused by the problem he is facing. Coping strategy means the individual's ability to deal with the stress of the problems that will not cause prolonged adverse effects. Coping strategies have three factors: problem-focused coping, emotion-focused coping, and seeking social support.

Problem-focused coping is a coping strategy that focuses on dealing with the problem at hand, which consists of analysing the causes of the problems encountered, planning steps to deal with the problem, and making efforts to change the situation carefully. Emotion-focused coping is a coping strategy that focuses on dealing with emotions that arise because of the problem. It consists of accepting one's shortcomings, directing, and releasing emotions, creating positive meaning to develop oneself, adjusting to circumstances that have occurred, controlling oneself so as not to deal with the problem in a hurry, and avoiding the same problem in the future. Finally, seeking social support is a form of coping strategy by seeking social support from the people around him, asking for information from family and friends, asking for emotional support from family and friends, and asking for advice from family and friends.

Several previous studies have developed a coping strategy scale, but it is slightly different from the scale developed at this time. For example, research from Sullivan (2010) aims to develop an academic coping strategy instrument and produces 
56 items consisting of three factors, namely approach factors (23 items), avoidance (19 items), and social support (14 items). The students from one university become the respondent for test this instrument. Thus, the research sample became homogeneous.

Another study conducted by Chesney et al. (2006) aims to develop a Coping Self-Efficacy (CSE) instrument consisting of coping strategy factors that focus on problems (6 items), stop unpleasant emotions and thoughts (4 items), and get support from friends and family (3 items). Again, the respondents are people who have chronic diseases.

This research is part of the standardization of the Students' Coping Strategy Scale (SCSS). This study reveals the students' coping strategy scale's content validity, empirical validity, and reliability. There are several types of coping strategies. This research is limited to the academic aspect, so that the instrument to be developed will focus on student coping strategies, including academic activities.

\section{METHOD}

This study reveals the content validity, empirical validity, and reliability of the SCSS. This study uses a quantitative approach with a survey method. The population for this study is all students in Universitas Negeri Jakarta, while the sample was selected using a simple random sampling technique. Content validity was analysed by giving coping strategy instruments to two experts in the field of Family Science. The expert will analyse the suitability between the coping strategy variables' indicators, factors, and theory. Then, the results of these observations were calculated using the Gregory content validity formula. The analysis of empirical validity and reliability was carried out by empirically testing the instrument on 211 respondents. Empirical validity and reliability were analysed using the Rasch model approach. At the beginning of the instrument development, 42 items developed from three factors: problem-focused coping, emotion-focused coping, and seeking social support. SCSS is a non-test instrument that has a Likert scale. The scale blueprint developed can be seen in table 1.

Table 1. Student coping strategy scale blueprint

\begin{tabular}{|c|c|c|c|c|c|}
\hline \multirow[t]{2}{*}{ No. } & \multirow[t]{2}{*}{ Factors } & \multirow[t]{2}{*}{ Indicators } & \multicolumn{2}{|c|}{ Item Number } & \multirow[t]{2}{*}{$\begin{array}{l}\text { Total } \\
\text { Items }\end{array}$} \\
\hline & & & + & - & \\
\hline \multirow[t]{3}{*}{1.} & \multirow{3}{*}{$\begin{array}{l}\text { Problem- } \\
\text { focused } \\
\text { coping }\end{array}$} & $\begin{array}{l}\text { Analysing the causes of } \\
\text { problems encountered }\end{array}$ & $1,2,3,4$ & & 4 \\
\hline & & $\begin{array}{l}\text { Planning steps for } \\
\text { problem-solving }\end{array}$ & 5,7 & 6 & 3 \\
\hline & & $\begin{array}{l}\text { Making efforts to change } \\
\text { the situation carefully }\end{array}$ & $8,9,10$ & 11 & 4 \\
\hline \multirow[t]{5}{*}{2.} & \multirow{5}{*}{$\begin{array}{l}\text { Emotion- } \\
\text { focused } \\
\text { coping }\end{array}$} & $\begin{array}{l}\text { Accepting one's } \\
\text { shortcomings }\end{array}$ & 12 & $\begin{array}{c}13,14 \\
15 \\
\end{array}$ & 4 \\
\hline & & $\begin{array}{l}\text { Directing and releasing } \\
\text { emotions }\end{array}$ & $\begin{array}{c}16,17 \\
20\end{array}$ & 18,19 & 5 \\
\hline & & $\begin{array}{l}\text { Creating positive meaning } \\
\text { to develop oneself }\end{array}$ & $\begin{array}{l}21,22, \\
23,24\end{array}$ & & 4 \\
\hline & & $\begin{array}{l}\text { Adjusting to circumstances } \\
\text { that have been occurs }\end{array}$ & 25 & $\begin{array}{c}26,27 \\
28 \\
\end{array}$ & 4 \\
\hline & & $\begin{array}{l}\text { Controlling the urge to deal } \\
\text { with rush }\end{array}$ & 29,30 & & 2 \\
\hline
\end{tabular}




\begin{tabular}{|c|c|c|c|c|c|}
\hline \multirow[t]{3}{*}{ No. } & \multirow[t]{3}{*}{ Factors } & \multirow[t]{2}{*}{ Indicators } & \multicolumn{2}{|c|}{ Item Number } & \multirow[t]{2}{*}{$\begin{array}{l}\text { Total } \\
\text { Items }\end{array}$} \\
\hline & & & + & - & \\
\hline & & $\begin{array}{l}\text { Avoiding the same } \\
\text { problem later }\end{array}$ & $\begin{array}{c}31,32 \\
33\end{array}$ & & 3 \\
\hline \multirow[t]{4}{*}{3.} & \multirow{4}{*}{$\begin{array}{l}\text { Seeking } \\
\text { social } \\
\text { support }\end{array}$} & $\begin{array}{l}\text { Asking for information from } \\
\text { family and friends }\end{array}$ & 34,35 & & 2 \\
\hline & & $\begin{array}{l}\text { Asking for emotional } \\
\text { support from family and } \\
\text { friends }\end{array}$ & $\begin{array}{l}36,38 \\
39\end{array}$ & 37 & 4 \\
\hline & & $\begin{array}{l}\text { Asking for advice from } \\
\text { family and friends }\end{array}$ & 40,42 & 41 & 3 \\
\hline & & otal Items & 30 & 12 & 42 \\
\hline
\end{tabular}

\section{RESULTS AND DISCUSSION}

The SCSS will go through content validation and construct validation. First, content validity was analysed by giving coping strategy instruments to two experts in Family Science. The expert will analyse the suitability between the coping strategy variables' indicators, factors, and theory. Then, the results of these observations were calculated using the Gregory content validity formula as follows.

$$
V i=\frac{D}{A+B+C+D}=\frac{30}{1+2+9+30}=\frac{30}{42}=0,714
$$

This figure shows that the interrater coefficient on the content validity of the SCSS is 0.714 . However, this coefficient is still lower than 0.75 (Gregory, 2007). So, it is necessary to revise the items considered unsuitable-the significant changes after validation in the items of the SCSS as in table 2. After revision, the SCSS is valid, which consists of 42 items.

Table 2. Improvement of items on the SCSS

\begin{tabular}{llll}
\hline No & Before Revision & \multicolumn{1}{c}{ After Revision } & \multicolumn{1}{c}{ Explanation } \\
\hline 19 & $\begin{array}{l}\text { I withdraw from other } \\
\text { people }\end{array}$ & $\begin{array}{l}\text { I withdraw from other } \\
\text { people when feel angry }\end{array}$ & $\begin{array}{l}\text { Become a positive item on } \\
\text { the same indicator }\end{array}$ \\
\hline 21 & I speak positively to \\
myself & $\begin{array}{l}\text { I cry in front of family or } \\
\text { friends when facing } \\
\text { problems }\end{array}$ & $\begin{array}{l}\text { Become a positive item on } \\
\text { the indicators of directing } \\
\text { and releasing emotions }\end{array}$ \\
\hline
\end{tabular}

After fulfilling content validity, this study involved 211 respondents in being able to validate the instrument empirically. The results of respondents' answers were analysed using the Rasch model approach with WINSTEPS software. The results of the analysis are in table 3.

Table 3. Summary of statistics

\begin{tabular}{clcc}
\hline No. & Statistical Measurement & Item & Person \\
\hline 1 & Mean Measure & 0,00 & 0,70 \\
\hline 2 & Reliability & 0,99 & 0,86 \\
\hline 3 & Infit Mean Square & 1,00 & 1,03 \\
\hline
\end{tabular}




\begin{tabular}{clcc}
\hline 4 & Outfit Mean Square & 1,02 & 1,02 \\
\hline 5 & Mean Infit Z-Standard & $-0,20$ & $-0,20$ \\
\hline 6 & Mean Outfit Z-Standard & $-0,10$ & $-0,20$ \\
\hline 7 & Separation & 9,95 & 2,47 \\
\hline
\end{tabular}

Based on the results of the statistical summary analysis above, a more detailed explanation is as follows.

a. A person's mean measure value is higher than the item's mean measure value, namely $0.70>0.00$. This value shows that the ability of respondents to respond to items did not balance with the ability of the developed statement. In general, respondents can understand all the items developed in the instrument.

b. The reliability value of the item is 0.99 , which indicates that the quality of the items developed in the SCSS is in a particular category. In comparison, the reliability value of the person is 0.86 , which means that the consistency of the response given by the respondent is in a suitable category.

c. The infit mean square of item value is 1.00 , while the infit mean square of person value is 1.03. Thus, the infit mean square of the item is exact 1.00 , and the infit mean square of person value is close to 1.00 . Thus, the developed SCSS fits with the model.

d. Outfit mean square of item and person both have a value of 1.02 . Both values are close to 1.00 . Thus, the developed SCSS fits with the model. The data provided by the respondent is not the result of guessing but the actual data.

e. Both mean infit $z$-standard items and person values are -0.20 . Both values are close to 0.00 , so the SCSS developed already fits the model.

$f$. The mean outfit $z$-standard item value is -0.10 , while the mean outfit $z$-standard person value is -0.20 . Both values are close to 0.00 , so the responses given by the respondents are actual data.

g. The value of the separation item is 9.95 , while the value of the separation person is 2.47 . Thus, to classify respondents' abilities in dealing with stress can use this SCSS.

Next, analyse each item by paying attention to the measured value, infit mean square, outfit mean square, and point measure correlation. An item considers unfit with the model if it has an infit mean square and an outfit mean square value of less than 0.50 or more than 1.50 (Safari, 2017). The infit mean square and outfit mean square values of SCSS are in table 4.

Table 4. Value of Measure, Infit Mean Square, Outfit Mean Square, and Point Measure Correlation Items

\begin{tabular}{cccccc}
\hline Item Number & Measure & Infit & Outfit & PTMEA & Decision \\
\hline 1 & -0.11 & 0.80 & 0.81 & 0.39 & fit \\
\hline 2 & -0.61 & 0.57 & 0.55 & 0.57 & fit \\
\hline 3 & -0.25 & 0.64 & 0.66 & 0.53 & fit \\
\hline 4 & 0.51 & 1.06 & 1.06 & 0.43 & fit \\
\hline 5 & -0.07 & 0.66 & 0.66 & 0.55 & fit \\
\hline 6 & -0.24 & 1.27 & 1.33 & 0.32 & fit \\
\hline
\end{tabular}




\begin{tabular}{|c|c|c|c|c|c|}
\hline Item Number & Measure & Infit & Outfit & PTMEA & Decision \\
\hline 7 & 0.12 & 0.73 & 0.74 & 0.45 & fit \\
\hline 8 & -0.10 & 0.73 & 0.76 & 0.50 & fit \\
\hline 9 & -1.03 & 0.87 & 0.85 & 0.38 & fit \\
\hline 10 & -0.63 & 0.52 & 0.53 & 0.61 & fit \\
\hline 11 & -0.17 & 1.31 & 1.43 & 0.35 & fit \\
\hline 12 & -0.41 & 1.09 & 1.15 & 0.24 & fit \\
\hline 13 & 0.14 & 0.94 & 1.00 & 0.39 & fit \\
\hline 14 & -0.49 & 1.13 & 1.13 & 0.32 & fit \\
\hline 15 & 1.31 & 1.18 & 1.19 & 0.32 & fit \\
\hline 16 & -0.39 & 0.71 & 0.71 & 0.41 & fit \\
\hline 17 & -1.25 & 0.90 & 0.79 & 0.54 & fit \\
\hline 18 & -0.36 & 1.68 & 1.67 & 0.33 & unfit \\
\hline 19 & -0.07 & 1.56 & 1.60 & 0.05 & unfit \\
\hline 20 & -0.38 & 0.89 & 0.88 & 0.47 & fit \\
\hline 21 & 1.61 & 1.48 & 1.50 & 0.20 & fit \\
\hline 22 & 1.74 & 1.27 & 1.37 & 0.21 & fit \\
\hline 23 & 0.63 & 0.93 & 0.93 & 0.42 & fit \\
\hline 24 & -0.23 & 1.07 & 1.04 & 0.31 & fit \\
\hline 25 & -0.87 & 0.60 & 0.61 & 0.54 & fit \\
\hline 26 & 0.15 & 1.43 & 1.48 & 0.30 & fit \\
\hline 27 & 2.28 & 1.54 & 1.89 & -0.27 & unfit \\
\hline 28 & -0.35 & 1.40 & 1.50 & 0.31 & fit \\
\hline 29 & -0.59 & 0.70 & 0.71 & 0.55 & fit \\
\hline 30 & -0.78 & 0.70 & 0.67 & 0.56 & fit \\
\hline 31 & -0.96 & 0.80 & 0.74 & 0.56 & fit \\
\hline 32 & -1.45 & 0.97 & 0.89 & 0.40 & fit \\
\hline 33 & -0.98 & 0.83 & 0.75 & 0.60 & fit \\
\hline 34 & 0.54 & 0.97 & 0.98 & 0.51 & fit \\
\hline 35 & 0.69 & 0.97 & 0.98 & 0.42 & fit \\
\hline 36 & 0.67 & 0.94 & 0.95 & 0.41 & fit \\
\hline 37 & 1.06 & 1.21 & 1.27 & 0.20 & fit \\
\hline
\end{tabular}




\begin{tabular}{cccccc}
\hline Item Number & Measure & Infit & Outfit & PTMEA & Decision \\
\hline 38 & 1.12 & 1.14 & 1.13 & 0.30 & fit \\
\hline 39 & 0.16 & 0.74 & 0.74 & 0.49 & fit \\
\hline 40 & 0.38 & 0.78 & 0.79 & 0.54 & fit \\
\hline 41 & -0.28 & 1.17 & 1.18 & 0.35 & fit \\
\hline 42 & -0.10 & 1.03 & 1.06 & 0.52 & fit \\
\hline
\end{tabular}

The analysis results show that item numbers 18,19 , and 27 have an infit mean square and an outfit square value of more than 1.5. Thus, from developing the 42 items, three items do not fit the model. Thus, the three items are recommended to be removed from the instrument. The rest, as many as 39 items, were fit in describing student coping strategies. Thus, the number of valid items in this study is more than the number of items developed by Sullivan (2010) but less than the instrument developed by Chesney et al. (2006).

The three items that do not fit the model come from the emotion-focused coping factor. Emotion-focused coping is a coping strategy that focuses on dealing with emotions that arise due to the problem at hand. Items that do not fit the model indicate that these items cannot measure how well students handle emotions.

The difficulty level of the item or known as the item's location is in the value range of -1.45 to 2.28. Based on its location, item number 27 measures adjust to the situation that has already occurred indicators, with the statement "I believe the problem will be resolved in time" being at 2.28 logit. Therefore, item number 27 is the most challenging item for respondents to agree on. While item number 32 , which measures avoids the same problem in the future indicators, with the statement "I do not want to repeat the same mistake," which is at -1.45 logit and is the most accessible item for respondents to agree on. Details of the item difficulty level are shown in Figure 1.

Furthermore, if the point measure correlation (PTMEA) is negative, the item does not have the correct score and does not function properly (Linacre, 2018). For example, based on table 4, one item has a negative correlation value, item number 27 , with a value of -0.27 . Besides item number 27 , the point measure correlation values of the other 41 items ranged from 0.05 to 0.61 . Thus, according to the theory, for 41 items, the statement has functioned well in the same direction.

Figure 1 shows the relationship between the items tested and the distribution of respondents. The left (person) shows that the higher the respondent has a $\mathrm{good} / \mathrm{high}$ coping strategy, the lower the respondent has a bad/low coping strategy. Meanwhile, on the right (item), the higher up means, the more complex the statement items are to be approved by the respondent, while the lower it means the respondent more easily approves the items. Based on Figure 1, quite many respondents have good coping strategies. More respondents are in a position above the average item difficulty level. So those respondents quickly agree upon more items. 


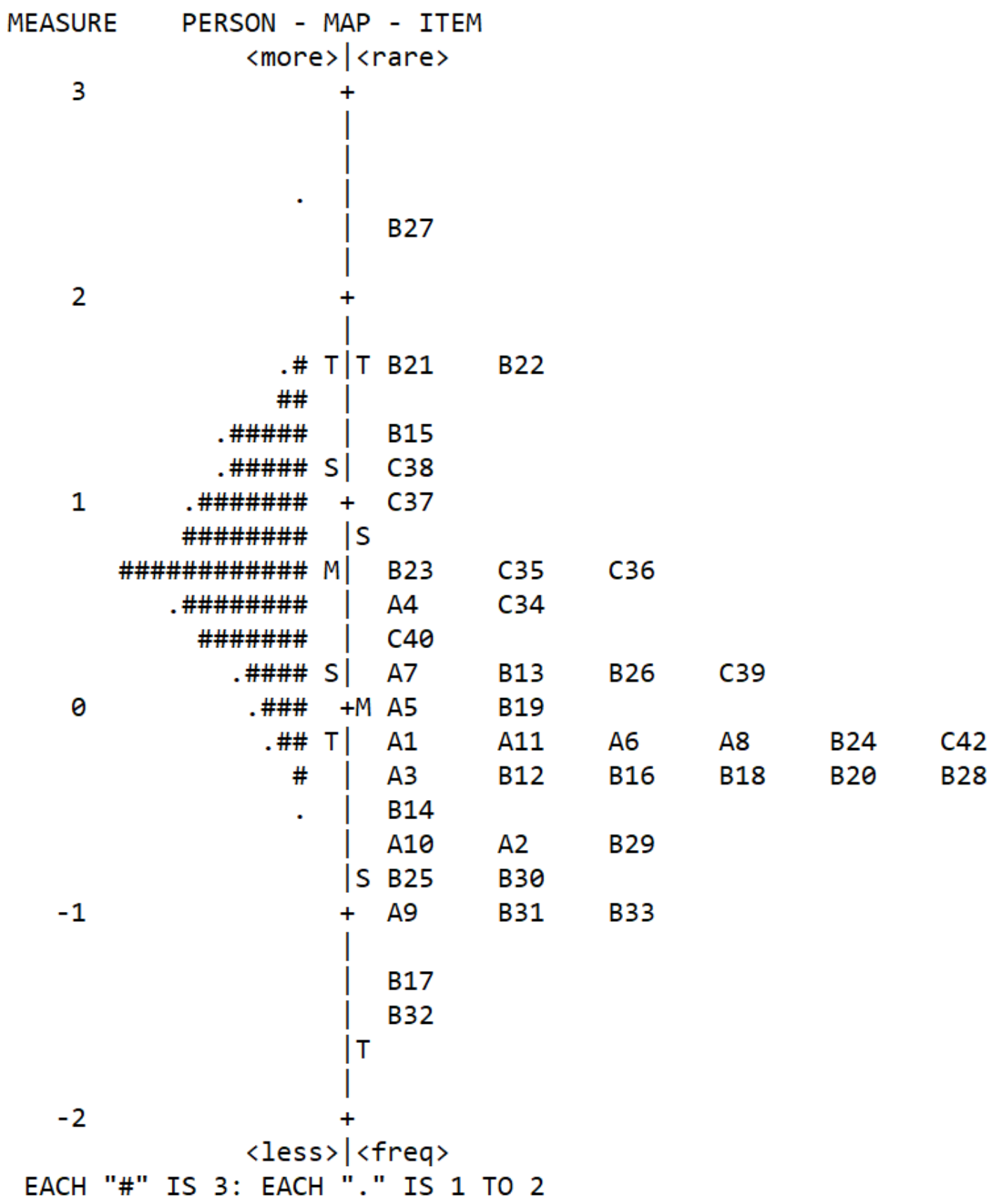

Figure 1. Item difficulty level

Based on the analysis results above, the psychometric characteristics of the SCSS were good. This characteristic looks from the analysis based on the infit mean square and outfit mean square values that have met the item's suitability with the model. In addition, it has met the criteria, judging from the level of difficulty and the point measure correlation value.

Analysing the suitability of items with the model resulted should delete three items: items number 18, 19, and 27. These three items came from the emotionfocused coping dimension. Items number 18 and 19 come from the indicator "directing and releasing emotions," while item number 27 comes from the indicator "adjusting to the situation that has happened." Item number 19 is an item that has gone through the revision stage when an expert carries out content validation. Thus, the Students Coping Strategy Scale (SCSS) with 39 statement items is feasible and can measure 
student responses in dealing with stress caused by the problems they face. The final grid of valid instruments is shown in table 5.

Table 5. Revised Students' Coping Strategy Scale Blueprint

\begin{tabular}{|c|c|c|c|c|c|}
\hline \multirow[t]{2}{*}{ No. } & \multirow[t]{2}{*}{ Factors } & \multirow[t]{2}{*}{ Indicators } & \multicolumn{2}{|c|}{ Item Number } & \multirow[t]{2}{*}{$\begin{array}{l}\text { Total } \\
\text { Items }\end{array}$} \\
\hline & & & + & - & \\
\hline \multirow[t]{3}{*}{1.} & \multirow{3}{*}{$\begin{array}{l}\text { Problem- } \\
\text { focused } \\
\text { coping }\end{array}$} & $\begin{array}{l}\text { Analysing the causes of } \\
\text { problems encountered }\end{array}$ & $1,2,3,4$ & & 4 \\
\hline & & $\begin{array}{l}\text { Planning steps for } \\
\text { problem-solving }\end{array}$ & 5,7 & 6 & 3 \\
\hline & & $\begin{array}{l}\text { Making efforts to change } \\
\text { the situation carefully }\end{array}$ & $8,9,10$ & 11 & 4 \\
\hline \multirow[t]{6}{*}{2.} & \multirow{6}{*}{$\begin{array}{l}\text { Emotion- } \\
\text { focused } \\
\text { coping }\end{array}$} & $\begin{array}{l}\text { Accepting one's } \\
\text { shortcomings }\end{array}$ & 12 & $\begin{array}{c}13,14 \\
15\end{array}$ & 4 \\
\hline & & $\begin{array}{l}\text { Directing and releasing } \\
\text { emotions }\end{array}$ & $\begin{array}{l}16,17 \\
18,19\end{array}$ & & 4 \\
\hline & & $\begin{array}{l}\text { Creating positive meaning } \\
\text { to develop oneself }\end{array}$ & $\begin{array}{c}20,21 \\
22\end{array}$ & & 3 \\
\hline & & $\begin{array}{l}\text { Adjusting to circumstances } \\
\text { that have been occurs }\end{array}$ & 23 & 24,25 & 3 \\
\hline & & $\begin{array}{l}\text { Controlling the urge to deal } \\
\text { with rush }\end{array}$ & 26,27 & & 2 \\
\hline & & $\begin{array}{l}\text { Avoiding the same } \\
\text { problem later }\end{array}$ & $\begin{array}{c}28,29 \\
30\end{array}$ & & 3 \\
\hline \multirow[t]{4}{*}{3.} & \multirow{4}{*}{$\begin{array}{l}\text { Seeking } \\
\text { social } \\
\text { support }\end{array}$} & $\begin{array}{l}\text { Asking for information from } \\
\text { family and friends }\end{array}$ & 31,32 & & 2 \\
\hline & & $\begin{array}{l}\text { Asking for emotional } \\
\text { support from family and } \\
\text { friends }\end{array}$ & $\begin{array}{c}33,35 \\
36\end{array}$ & 34 & 4 \\
\hline & & $\begin{array}{l}\text { Asking for advice from } \\
\text { family and friends }\end{array}$ & 37,39 & 38 & 3 \\
\hline & & otal Items & 30 & 9 & 39 \\
\hline
\end{tabular}

\section{CONCLUSION}

Based on the analysis result, the conclusions are:

1. The results of the content validity analysis show that Gregory's coefficient of content validity is 0.714 . On items deemed unsuitable, require revision. Based on the results of the expert test, two items are not appropriate.

2. The results of the empirical validity analysis show that 39 items have an infit mean square (IMNSQ) and outfit mean square (OMNSQ) value between 0.5 to 1.5. Thus, the final students' coping strategy scale will not include items with IMNSQ $<0.5$ or IMNSQ $>1.5$ and OMNSQ $<0.5$ or OMNSQ $>1.5$.

3. The value of the reliability coefficient of the students' coping strategy scale is 0.99 , which means that the instrument is reliable to measure the coping strategy. Thus, the 39 items of the statement are appropriate for measuring students' coping strategies. 


\section{Acknowledgment}

The Public Service Agency funded this research for Operational Instructions for the Activities of the Faculty of Engineering, Universitas Negeri Jakarta, based on the decision of the commitment-making official No. 291/UN39/PT.01.02/2021 and a letter of assignment agreement for the dean of the Faculty of Engineering No 094a/5.FT/PP/IV/2021.

\section{REFERENCE}

Chesney, M. A., Neilands, T. B., Chambers, D. B., Taylor, J. M., \& Folkman, S. (2006). A validity and reliability study of the coping self-efficacy scale. British Journal of Health Psychology, 11, 421-437. https://doi.org/10.1348/135910705X53155

Evandio, A. (2020). Pemerataan jaringan Internet $3 T$ Belum Optimal. https://teknologi.bisnis.com/read/20200705/84/1261845/pemerataan-jaringaninternet-3t-belum-optimal

Gregory, R. (2007). Psychological testing: history, principle, and applications (5th ed). Pearson Education Group.

Kemendikbud. (2020). Kemendikbud Terbitkan Pedoman Penyelenggaraan Belajar dari Rumah. Kemendikbud. https://www.kemdikbud.go.id/main/blog/202/05/kemendikbud-terbitkanpedoman-penyelenggaraan-belajar-dari-rumah

Linacre, J. M. (2018). Winsteps ${ }^{\circledR}$ Rasch measurement computer program user's guide. Winsteps.com.

Lubis, R., Irma, N. H., Wulandari, R., Siregar, K., Tanjung, A., Wati, T. A., N, M. P., \& Syahfitri, D. (2015). Coping Stress pada Mahasiswa yang Bekerja. Jurnal Diversita, 1(2), 48-57.

Oktaviani, M., Zulfa, V., \& Elmanora. (2020). What platform makes students enjoy the learning during covid-19 pandemic? Proceeding "International Webinar on Education 2020," 102-107.

Rustiana, E. R., \& Cahyati, W. H. (2012). Stress Kerja dengan Pemilihan Strategi Coping. Jurnal Kesehatan Masyarakat, 7(2), 149-155.

Safari. (2017). Analisis data dengan Program Komputer: Excel, SPSS, Iteman, Winsteps, Quest, Rascal, Ascal, Bilog, Parscale, Facets, Lisrel, Amos, dan Mplus. Universitas Negeri Jakarta.

Sullivan, J. R. (2010). Preliminary Psychometric Data for the Academic Coping Strategies Scale. Assessment for Effective Intervention, 35(2), 114-127. https://doi.org/10.1177/1534508408327609

United Nations. (2021). Ensure inclusive and equitable quality education and promote lifelong learning opportunities for all. https://unstats.un.org/sdgs/report/2020/goal04/

Utami, A. B., \& Pratitis, N. T. (2013). Peran Kreativitas Dalam Membentuk Strategi Coping Mahasiswa Ditinjau Dari Tipe Kepribadian Dan Gaya Belajar. Persona, Jurnal Psikologi Indonesia, 2(3), 232-247. 